\title{
Treatment of Adult-Acquired Buried Penis
}

\author{
W. Britt Zimmerman ${ }^{1,2}$ and Richard A. Santucci ${ }^{1,2}$ \\ ${ }^{1}$ Michigan State University - College \\ of Osteopathic Medicine \\ ${ }^{2}$ Detroit Receiving Hospital \\ Detroit Medical Center \\ United States of America
}

\section{Introduction}

The first know description of buried penis was by Keyes in 1919. Buried penis was described as the "absence of the penis exists when the penis, lacking its proper sheath of skin, lies buried beneath the integument of the abdomen, thigh or scrotum (Keyes, 1919)." Classically, the entity of buried penis has been primarily discussed in the pediatric population (Boemers \& De Jong, 1995, Crawford, 1977, Donatucci \& Ritter, 1998, Lim et al., 1995, Maizels et al., 1986, McCahill et al., 1995, Wollin et al., 1990). However, a buried penis afflicts many adults leaving them with the inability to have sexual relations, practice personal hygiene, or stand to void since they are unable to direct their penis during micturition (Cromie et al., 1998). Unlike the pediatric patient population, adults with buried penis have acquired this condition as a result of obesity, over exuberant circumcision, scarring due to lichen sclerosis et atrophicus (previously as known as balanitis xerotica obliterans) or lymphedema (Alici et al., 1998, Chopra et al., 2002, Donatucci \& Ritter, 1998, Sivakumar et al., 2004, Tang et al., 2008). This chapter discusses the pathophysiology of a buried penis, patient selection for operative management, and surgical management with associated complications.

\section{History of buried penis management}

Since the initial description by Keyes and colleagues, various names have been associated with "buried penis" which describes the pathology in both the pediatric and adult population. These names range from buried penis (Keyes, 1919), concealed penis (Wollin et al., 1990) webbed penis (Crawford, 1977), and inconspicuous penis (Maizels et al., 1986). In 1951, Campbell and colleagues described the buried penis as being underneath the perineum, hypogastrium, thigh, or subcutaneous fat of scrotum (Campbell, 1951). Usually, buried penis and concealed penis are used interchangeably (Glanz, 1968).

Two authors have offered classification systems in identifying buried penis. In 1977, Crawford proposed three categories: concealed penis, buried penis (partial or complete) and penoscrotal webs (Crawford, 1977). Later in 1986, Maizels proposed a classification system in four categories: buried penis, webbed penis, trapped penis, and micropenis (Maizels et al., 1986) (Table 1). 


\begin{tabular}{|c|l|l|}
\hline \multicolumn{2}{|c|}{ Buried Penis Classification } \\
\hline & \multicolumn{1}{|c|}{ Crawford's Classification } & \multicolumn{1}{c|}{ Maizel's Classification } \\
\hline 1 & Concealed penis & Buried penis \\
\hline 2 & Buried penis (partial or complete) & Webbed penis \\
\hline 3 & Penoscrotal webs & Trapped penis \\
\hline 4 & & Micropenis \\
\hline
\end{tabular}

Table 1. Buried penis classification systems

\section{Etiology}

The underlying pathological process of a buried penis includes an abnormal hypermobility of the ventral skin on dartos fascia and inadequate attachments to the underlying Buck's fascia. The corpora remains stationery and the surrounding tissues (skin and dartos) migrate distally (Alter \& Ehrlich, 1999, Casale et al., 1999, Frenkl et al., 2004). Hence, the overlying penile skin acts as a redundant drape, or "tent pole" over which skin is draped. The process may advance because the corporal bodies remain fixed to the pubic bone by the suspensory ligament and because of this fixation, the obese patient's abdomen descends and envelopes the penis. As the penis becomes covered or "buried," excessive moisture begins to develop which then promotes bacterial overgrowth, tissue maceration, and infection. As chronic infections continue and a cycle is established, there is a perpetuation of skin breakdown followed by more inflammation and scarification. In addition, the patient is unable to direct their penis for voiding resulting in urine soilage. Urine is trapped and the cycle continues. Most patients are obese and have associated comorbidities such as diabetes mellitus, which may worsen the patient's prognosis (Donatucci \& Ritter, 1998).

\section{Patient presentation / selection}

Many patients present to their primary care physician or Urologist with in the inability to participate in sexual activity secondary to painful erections or the inability to achieve adequate penile length (Chopra et al., 2002, Cromie et al., 1998) (Figure 1). Additionally, patients may also suffer from social embarrassment, recurrent balanitis, and psychological stress (Chopra et al., 2002, Frenkl et al., 2004).

When selecting patients for surgical correction, many indications exist. Frankl et al (2004) describes; in the pediatric population indications for surgery which include recurrent balanitis, secondary phimosis, difficulty holding the penis during voiding, urinary stream spraying, social embarrassment, and parent's concern for future social embarrassment (Frenkl et al, 2004). These are widely accepted (Adham et al., 2000, Alici et al, 1998, Chuang et al., 2001, Donatucci \& Ritter, 1998, Frenkl et al., 2004). However, in dealing with the adult population, the primary indications are related to sexuality. Other indications include complete or partial penile concealment with the inability to stand to void, chronic urinary 
soilage, dysuria, inability to participate in penetrative intercourse, and erectile pain (Donatucci \& Ritter, 1998, Tang et al., 2008).

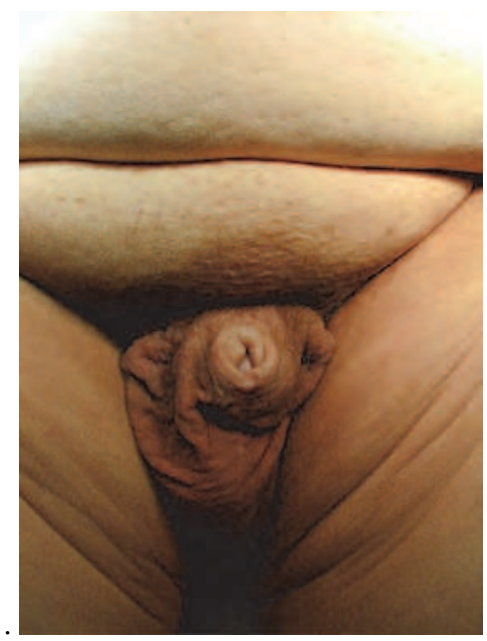

A)

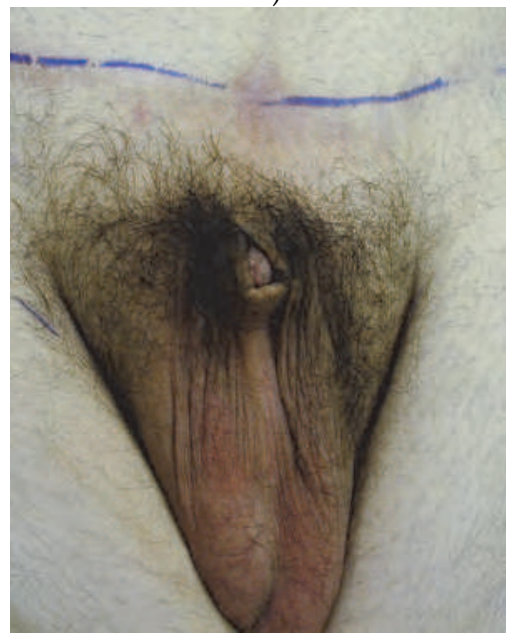

C)

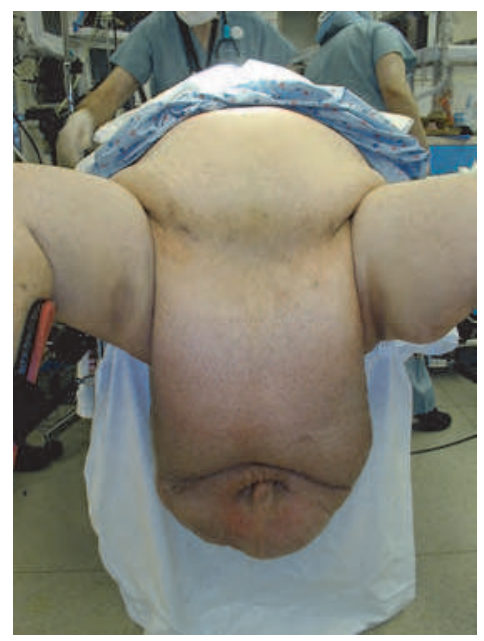

B)

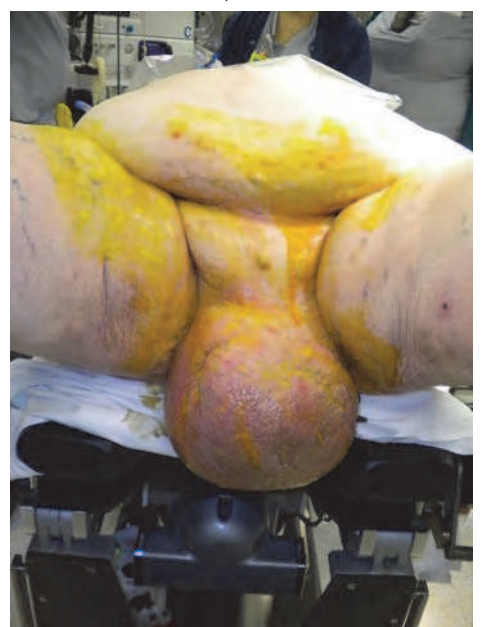

D)

Fig. 1. Buried penis etiologies vary: widely A: Large abdominal pannus, escutcheon and normal size scrotum. B: Large abdominal pannus and severe scrotal lymphedema. C: Buried penis following abdominoplasty, note normal abdomen and scrotum. D: Buried penis as a result of scrotal lymphedema.

The ideal candidates for operative correction of a buried penis are patients who are motivated and prepared for postoperative wound care. Wound complications are reported post-operatively, and these can be significant (Anaya \& Dellinger, 2006, Rogliani et al., 2006). Additionally, the patient must be medically and cardiovascular cleared for general anesthesia. 


\section{Patient preparation}

Patient education is paramount during pre-operative management. Many of these patients suffer from depression and some have even considered suicide in the past (Tang et al., 2008). Hence, the patient should be made aware of the extensive postoperative course that will ensue. Obesity and their abdominal girth often have a negative impact on wound healing and may limit their dexterity and ability to care for the groin wounds (Anaya \& Dellinger, 2006, Rogliani et al., 2006).

\section{Surgical technique}

Major reconstructive urologic surgery is required to treat adults with a buried penis. Many techniques have been described. The objectives are all primarily the same: restore the normal anatomy from the underlying pathological process.

Surgical approaches vary and should correlate to the etiology of the buried penis. Some patients present with a normal sized scrotum and abdomen without a pannus (Figure 2). In corollary, many patients suffer from a lack of penile skin as in an over exuberant circumcision. In simple situations like this, the penile skin is released and approximated to the base of the penile shaft, and the defect is covered by split thickness skin grafts. In more complicated scenarios, as in a patient with scrotal lymphedema or an abnormally large abdominal pannus, a more aggressive reconstructive surgical approach is mandated.

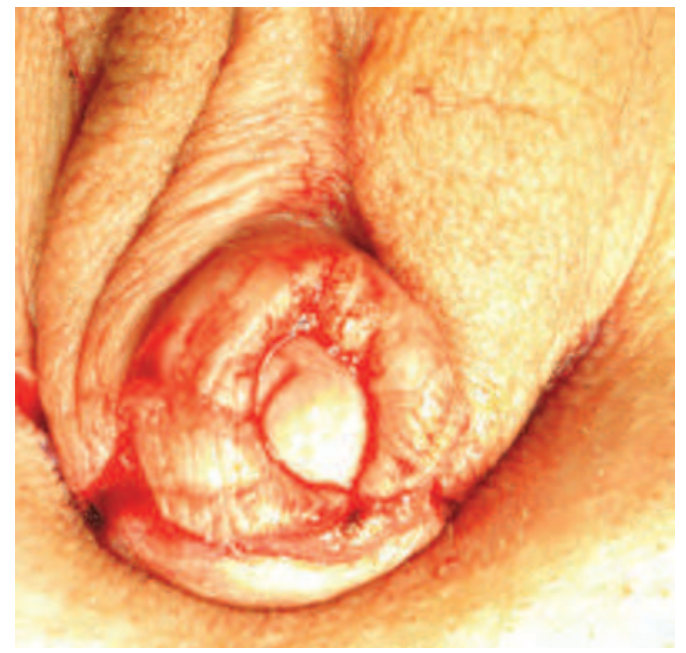

Fig. 2. Buried penis with normal abdomen and scrotal skin and poor penile shaft skin

Various surgical techniques for buried penis have been reported. Maizels et al. (1986) performed a lipectomy of the suprapubic fat pad and suspensory ligament incision. This was accompanied by pubic bone anchoring of the penopubic tissue (Maizels et al, 1986). Similarly, Alter and colleagues (1999) advocated securing the subdermis of the penoscrotal junction to the tunica albugenia ventrally to stabilize the penile and scrotal skin and prevent migration of the penis within the scrotum. Additionally, these authors advocate securing the subdermal penopubic junction to the rectus abdominal fascia (Alter \& Ehrlich, 1999). 
Wollin et al. (1990) described a complete degloving of penis with lysis of improper ventral dartos attachments. This is followed by an island pedicle flap of preputial skin and transposed to the ventral aspect of the penis (Wollin et al., 1990).

Donatucci et al. (1998) described a treatment algorithm ranging from release of scar contracture and primary closure. If insufficient release of the phallus occurs, then procession to panniculectomy is warranted. Depending on the adequacy of skin or soft tissue in for closure, the next step would be initially to use primary skin closure versus Z-plasty. If native skin is not available and/or of poor quality, then split thickness skin grafts or flaps may be necessary. Skin flaps should only be used when an inadequate graft bed exists (Donatucci \& Ritter, 1998). Chopra et al. (2002) described a technique using a large elliptical panniculectomy with scar excision and penile skin removal. Division of the suspensory ligament of the penis, release of the cicatrix and reattachment of the suspensory ligament of the penis should be undertaken if necessary. Finally, a standard abdominoplasty and full thickness skin grafting to the penis is performed. Skin grafting should be performed in a spiral fashion to diminish any linear scar contraction (Chopra et al., 2002).

Many authors have also addressed the obese patient's overlying suprapubic fat pad by performing dermatolipectomy or suction lipectomy with abdominoplasty (Adham et al., 2000, Alter \& Ehrlich, 1999, Horton et al., 1987).

Six principles for success have been summarized in the buried penis patient population by Chopra et al. (2002) (Table 2). First, release of the underlying cicatrix or scar which has anchored the penile tissue preventing it from being mobilized, should occur. Secondly, the majority of the pannus should be removed in the obese patient. Third, with the reduction of the abdominal fat pad, there is a need to reestablish the normal male escutcheon (suprapubic fat pad). The next step, in patients with a normal scrotum, is to reapproximate the median raphe of the scrotum to its' normal anatomic position at the base of the penis. Then, skin resurfacing must be carried out depending on the condition of the penile shaft. This can be achieved with either skin grafts or flaps. However, in the adult patient, non-hair bearing coverage is preferred. Finally, an appropriate dressing needs to be applied as the fragility of the skin graft must be respected (Chopra et al., 2002).

\section{Six Principles for Successful Buried Penis Management}

\begin{tabular}{|c|l|}
\hline 1 & Release/excision of cicatrix \\
\hline 2 & Removal of as much pannus as possible \\
\hline 3 & Reestablishment of normal male escutcheon \\
\hline 4 & Reattachment of median raphe to the base of the penis \\
\hline 5 & $\begin{array}{l}\text { Resurfacing the denuded penis with a full-thickness skin graft, sutured in spiral } \\
\text { fashion to avoid linear contracted scarring }\end{array}$ \\
\hline 6 & $\begin{array}{l}\text { Circumferential generic foam dressings applied snugly around the graft for } \\
\text { immobilization and splinting }\end{array}$ \\
\hline
\end{tabular}

Table 2. Six principle for successful surgical management of buried penis by Chopra et al. 
A different surgical approach is described by Tang et al. (2008). This technique in the obese patient includes escutcheonectomy, scrotoplasty, and penile split-thickness grafting with fibrin glue fixation (Tang et al., 2008). This begins with a circumcision incision two to three millimeters proximal to the coronal sulcus. This allows for complete exposure of the glans penis and penile shaft. The penoscrotal webs and aberrant scrotal tissues are released if necessary. If a scrotoplasty is performed, the wound is closed in a two layers and no drain is placed. The escutcheonectomy is made using an elliptical incision and juxtaposition to the base of the penis. We trim any redundant suprapubic fat and secure it as a flap to the superficial suspensory ligaments of the penis using 2-O interrupted polyglactin sutures (Figure 3). We make every effort to close all potential spaces to avoid seroma formation. Closed suction drains are used under the escutcheon flap wherever necessary.

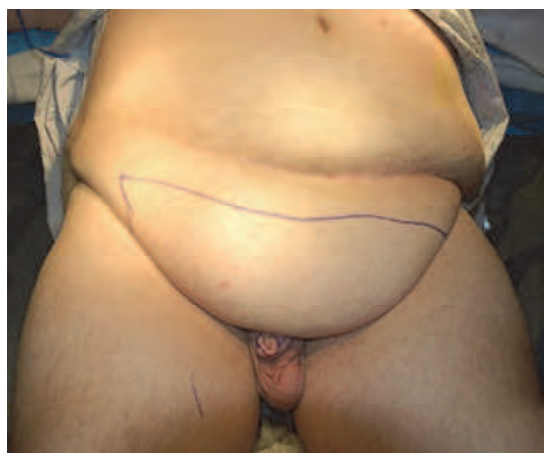

A)

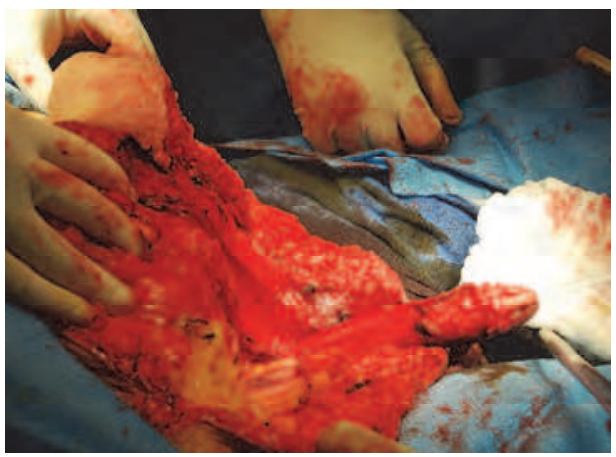

B)

Fig. 3. A: An elliptical incision is made on pannus. B: dermatolipectomy is performed.

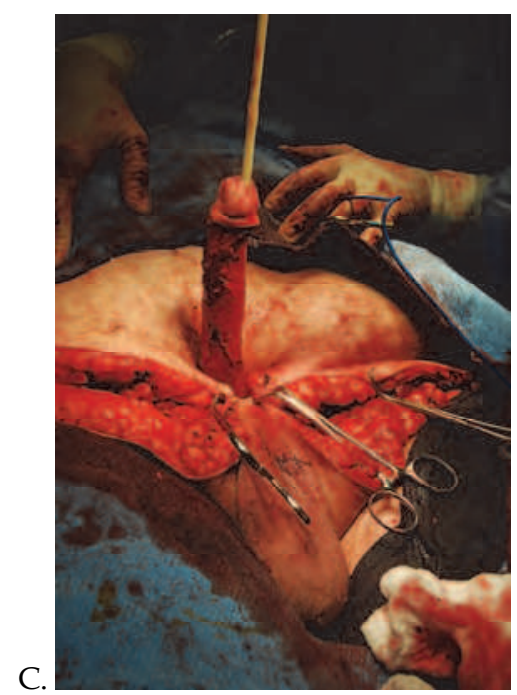

Fig. 3. C: The male escutcheon is reestablished. 
In our experience, the remaining penile shaft skin is either non-existent or of poor quality. Hence, we use full thickness skin grafts from the discarded escutcheon or split skin grafts (STSG) from a predetermined location, typically anterior left thigh. The STSG is harvested at a depth of 0.012 to 0.015 inches, using an electric dermatome. The proximal aspect of the skin graft is tacked down using multiple simple interrupted absorbable sutures. To assist in graft success, we use a diluted fibrin sealant (freeze-dried Tissel VH, Baxter, Deerfield, IL) as per manufacturer specifications. We spray the sealant to the entire surface of the penile shaft using the Tissomat fibrin glue spray device (Baxter). By using the dilute fibrin glue concentration (about $10 \%$ of the normal calcium concentration of Tissel), we lengthen the time to hardening from seconds to minutes which allows more time for the final graft placement (Figure 4).

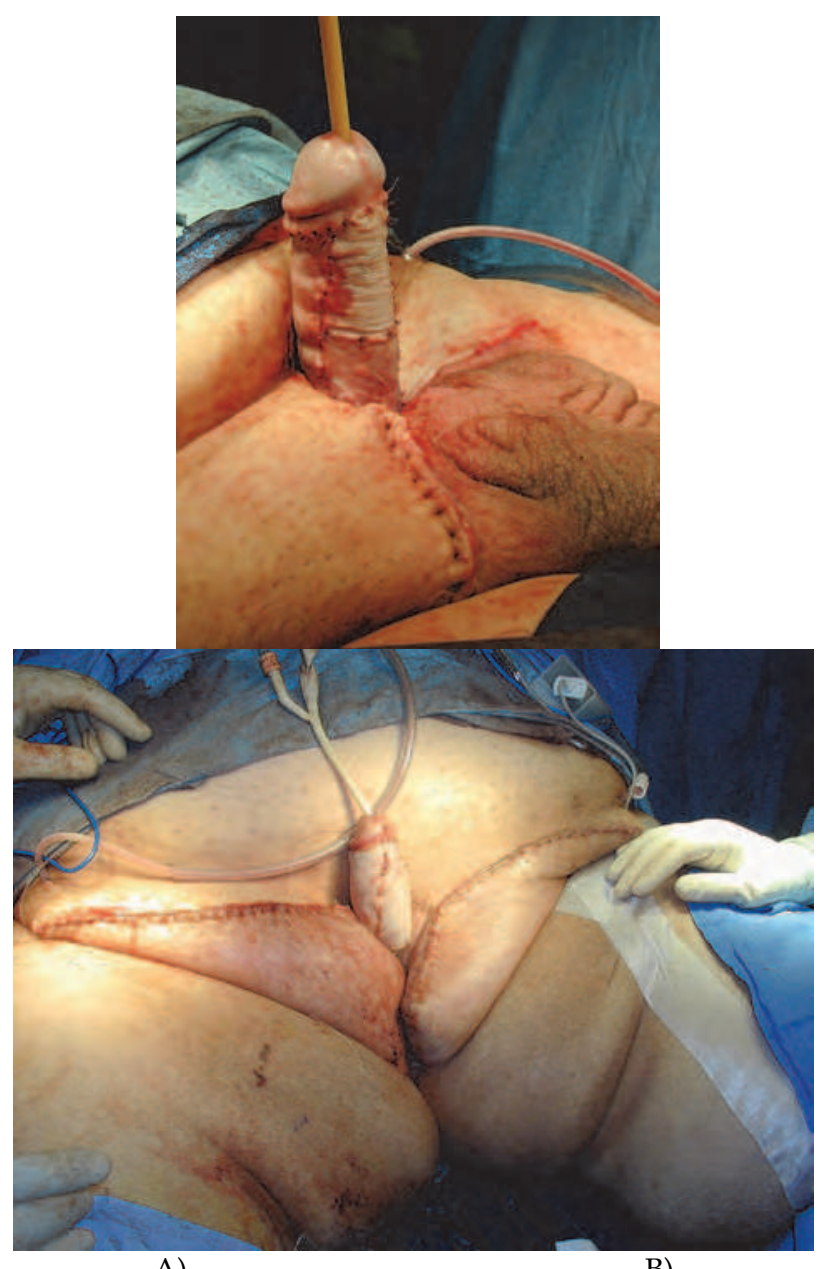

A)

B)

Fig. 4. A: Excision of the pannus and skin grafting. B: Pannus excision, scrotoplasty and skin grafting. 
The skin graft harvest site is covered with a transparent adhesive dressing (Opsite, Smith \& Nephew, London UK) and a small closed suction drain (TLS, Porex Surgical, Newman, GA). This type dressing removes excessive drainage and facilitates the dressing staying longer. The grafted penis is dressed in a 6 inch elastic antimicrobial gauze (Kerlix, Tyco/Kendall, Manfield, MA). Local anesthesia is used with $0.5 \%$ bupivacaine containing epinephrine 1:200,000 to lessen any postoperative pain. The skin graft dressing is removed after 24 hours and any seromas (blebs) are incised as necessary.

\section{Postoperative care}

Immediate postoperative care begins in the hospital. Our patients are admitted to the hospital and are on bed rest for the first three days. On postoperative day four, the patient returns to normal activity and is educated on wound care. Discharge typically takes place on postoperative day five. The patient is continued with oral antibiotics such as amoxicillin/clavulanate for two weeks. The patient is instructed to shower and dress the wounds daily. We recommend 4-inch gauze sponges (eg, Johnson \& Johnson "Topper" dressing sponges, or other nonadherent absorbent pads). We recommend against "open weave" gauze sponges as these have a tendency to debride and can result in surgical site breakdown.

\section{Complications}

In the postoperative period, complications can occur. These can range from surgical site infections to the development of a pulmonary embolism (Tang et al., 2008). In patients suffering from obesity and metabolic syndromes such as diabetes, an increased risk for Surgical Site Infection exists (Anaya \& Dellinger, 2006, Rogliani et al., 2006). Patients may also experience erectile dysfunction (ED) postoperatively. The erectile dysfunction may be due to an underlying disease process that initially propagated the buried penis. Hence, ED may only be recognized after the penis is once again revealed. It is also common for the patient to experience decreased sensation over the skin graft site (Donatucci \& Ritter, 1998). This will typically improve over time as nerve re-growth occurs.

The most common defense against the aforementioned complications beyond preoperative medical optimization and stringent perioperative care is education. The buried penis patient has often been described as being at the "end of their rope (Tang et al., 2008)." Hence, informed consent and patient expectations need to be framed appropriately.

\section{Conclusion}

Acquired adult buried penis management is a challenging reconstructive surgery. However, with the proper use of escutcheonectomy, reduction of the suprapubic fat pad, +/scrotoplasty, and with use of full or split thickness skin grafting, excellent results are possible. With diligent post-operative wound care to manage minor infections and wound dehiscence, the patient can return to sexual activity, have profound improvement in urinary function, and improved self-esteem as a result of improved cosmesis.

\section{Acknowledgement}

The author would like to acknowledge Dr. Lisa Hall Zimmerman for her dedicated assistance of manuscript editing. 


\section{References}

Adham MN, Teimourian B, Mosca P. (2000). Buried penis release in adults with suction lipectomy and abdominoplasty. Plastic and Reconstructive Surgery, 106, 840-4.

Alici B, Culha M, Ozkara H, Akkus E, Hattat H. (1998). Management of buried penis in adults. Urologia Internationalis, 61, 183-5.

Alter GJ, Ehrlich RM. (1999). A new technique for correction of the hidden penis in children and adults. The Journal of Urology, 161, 455-9.

Anaya DA, Dellinger EP. (2006). The obese surgical patient: a susceptible host for infection. Surgical Infections, 7, 473-80.

Boemers TM, De Jong TP. (1995). The surgical correction of buried penis: a new technique. The Journal of Urology, 154, 550-2.

Campbell M. (1951). Embryology and anomalies of the urogenital tract. In: Clinical Pediatric Urology, pp. 273 W. B. Saunders Co. Philadelphia

Casale AJ, Beck SD, Cain MP, Adams MC, Rink RC. (1999). Concealed penis in childhood: a spectrum of etiology and treatment. The Journal of Urology, 162, 1165-8.

Chopra CW, Ayoub NT, Bromfield C, Witt PD. (2002). Surgical management of acquired (cicatricial) buried penis in an adult patient. Annals of Plastic Surgery, 49, 545-9.

Chuang JH, Chen LY, Shieh CS, Lee SY. (2001). Surgical correction of buried penis: a review of 60 cases. Journal of Pediatric Surgery, 36, 426-9.

Crawford BS. (1977). Buried penis. British Journal of Plastic Surgery, 30, 96-9.

Cromie WJ, Ritchey ML, Smith RC, Zagaja GP. (1998). Anatomical alignment for the correction of buried penis. The Journal of Urology, 160, 1482-4.

Donatucci CF, Ritter EF. (1998). Management of the buried penis in adults. The Journal of Urology, 159, 420-4.

Frenkl TL, Agarwal S, Caldamone AA. (2004). Results of a simplified technique for buried penis repair. The Journal of Urology, 171, 826-8.

Glanz S. (1968). Adult congenital penile deformity. Case report. Plast Reconstr Surg, 41, 57980.

Horton CE, Vorstman B, Teasley D, Winslow B. (1987). Hidden penis release: adjunctive suprapubic lipectomy. Annals of Plastic Surgery, 19, 131-4.

Keyes EL. (1919). Phimosis-paraphimosis-tumors of the penis. . In: Urology, pp. 649 D. Appleton \& Co. New York, NY

Lim DJ, Barraza MA, Stevens PS. (1995). Correction of retractile concealed penis. The Journal of Urology, 153, 1668-70.

Maizels M, Zaontz M, Donovan J, Bushnick PN, Firlit CF. (1986). Surgical correction of the buried penis: description of a classification system and a technique to correct the disorder. The Journal of Urology, 136, 268-71.

McCahill PD, Leonard MP, Jeffs RD. (1995). Epispadias with phimosis: an unusual variant of the concealed penis. Urology, 45, 158-60.

Rogliani M, Silvi E, Labardi L, Maggiulli F, Cervelli V. (2006). Obese and nonobese patients: complications of abdominoplasty. Annals of Plastic Surgery, 57, 336-8.

Sivakumar B, Brown AA, Kangesu L. (2004). Circumcision in 'buried penis'--a cautionary tale. Annals of the Royal College of Surgeons of England, 86, 35-7. 
Tang SH, Kamat D, Santucci RA. (2008). Modern management of adult-acquired buried penis. Urology, 72, 124-7.

Wollin M, Duffy PG, Malone PS, Ransley PG. (1990). Buried penis. A novel approach. British Journal of Urology, 65, 97-100. 


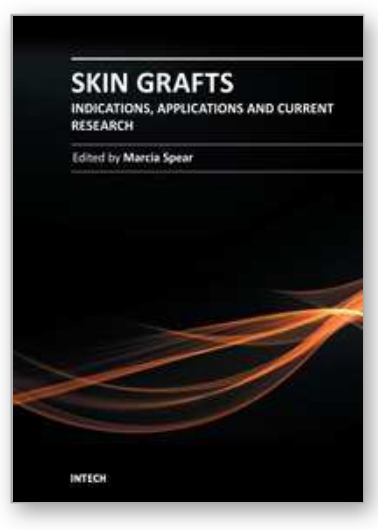

\author{
Skin Grafts - Indications, Applications and Current Research \\ Edited by Dr. Marcia Spear
}

ISBN 978-953-307-509-9

Hard cover, 368 pages

Publisher InTech

Published online 29, August, 2011

Published in print edition August, 2011

The procedure of skin grafting has been performed since 3000BC and with the aid of modern technology has evolved through the years. While the development of new techniques and devices has significantly improved the functional as well as the aesthetic results from skin grafting, the fundamentals of skin grafting have remained the same, a healthy vascular granulating wound bed free of infection. Adherence to the recipient bed is the most important factor in skin graft survival and research continues introducing new techniques that promote this process. Biological and synthetic skin substitutes have also provided better treatment options as well as HLA tissue typing and the use of growth factors. Even today, skin grafts remain the most common and least invasive procedure for the closure of soft tissue defects but the quest for perfection continues.

\title{
How to reference
}

In order to correctly reference this scholarly work, feel free to copy and paste the following:

W. Britt Zimmerman and Richard A. Santucci (2011). Treatment of Adult-Acquired Buried Penis, Skin Grafts Indications, Applications and Current Research, Dr. Marcia Spear (Ed.), ISBN: 978-953-307-509-9, InTech, Available from: http://www.intechopen.com/books/skin-grafts-indications-applications-and-currentresearch/treatment-of-adult-acquired-buried-penis

\section{INTECH}

open science | open minds

\section{InTech Europe}

University Campus STeP Ri

Slavka Krautzeka 83/A

51000 Rijeka, Croatia

Phone: +385 (51) 770447

Fax: +385 (51) 686166

www.intechopen.com

\section{InTech China}

Unit 405, Office Block, Hotel Equatorial Shanghai

No.65, Yan An Road (West), Shanghai, 200040, China

中国上海市延安西路65号上海国际贵都大饭店办公楼 405 单元

Phone: +86-21-62489820

Fax: +86-21-62489821 
(C) 2011 The Author(s). Licensee IntechOpen. This chapter is distributed under the terms of the Creative Commons Attribution-NonCommercialShareAlike-3.0 License, which permits use, distribution and reproduction for non-commercial purposes, provided the original is properly cited and derivative works building on this content are distributed under the same license. 